\title{
Serine Protease
}

National Cancer Institute

\section{Source}

National Cancer Institute. Serine Protease. NCI Thesaurus. Code C17123.

Proteases that have a serine residue in the active center of the enzyme. These enzymes catalyze the hydrolysis of covalent peptidic bonds by serine nucleophilic attack. Serine proteases participate in a wide range of functions in the body, including blood clotting, inflammation, and digestion. 